\title{
THE METHOD OF CONSTRUCTION OF UKRAINIAN BUSINESS-SYSTEM PROFILE
}

\author{
Olena Khanova \\ Department of Foreign Economic Relations and Touristic Business \\ V. N. Karazin Kharkiv National University, Kharkiv, Ukraine \\ 6 Svobody sq., Kharkiv, Ukraine, 61022 \\ khanovaelena@ukr.net \\ Nataliya Shkil \\ Simon Kuznets Kharkiv National University of Economics Kharkiv \\ 9-A Nauky ave., Kharkiv, Ukraine, 61166 \\ shkilnatalia@gmail.com
}

\begin{abstract}
Under conditions of crisis transformations at the national level, the absence of constant trends of development of economy and business-system as a whole there was carried out the analysis of Ukrainian business-system functioning in the context of 8 world ratings (business doing easiness; rating of national brands; rating of global competitiveness; rating of budget transparence; rating of investment attractiveness; rating of autosorcing attractiveness; index of economic freedoms; index of trade facilitation) that gives a possibility to assess the place of Ukraine in the global conditions of development comparing with the state of business-system development in other countries of the world.
\end{abstract}

Keywords: business-system, world ratings, global conditions of development.

\section{Introduction}

Globalization and internationalization of the world economic processes determine the modern order in economic space, formalizing the individualistic needs and the methods of their provision in wide-ranging dimensions, integrating the modern sovereign states, markets and technologies that allows any subject of economic activity to set the deeper contacts with partners, living throughout the world, faster and with minimal expenditures. International business is a product of this phenomenon, which forms are for today the most spread methods of getting profit under conditions of convergence of socio-economic, political-legal, technique-technological and religious-cultural standards.

International bank is a part of general system of international economic relations that corresponds to the relations, connected with business activity of industrial, commercial, monetary-financial types and so on. The very growth and close interlacing of these economic interests conditioned the urgent need in the study of theoretical preconditions, tendencies and regularities of international business development. Based on it, the recomposition of business-system gains the features of complexity and interdependence, becoming a kernel that determines the competitive positions of the country on the world market, its economic and technological priorities.

This question is especially urgent for Ukraine that claims to be recognized as an equal participant of the global business-community. Under conditions of permanent crisis situation that influences all internal and external economic processes in the country, the node factor is a construction of qualitatively new economic model that could eliminate the disproportions of national economic development, balance the regulating mechanisms of international business and strengthen international competitive positions of the country on the global market.

\section{Analysis of literary data and statement of the problem}

The study of business-systems is rather urgent theme in both Ukrainian and foreign scientists, but the works of other scientists are concentrated on: theoretical aspects of business-system functioning [1], financial aspects [2-5], the features of financial systems development in separate countries of the world (countries of Asia, Europe, USA) [4-10]. As opposite to the author's results, 
the analysis of business-systems of separate countries includes basic studies, in dynamics, but they are limited by indicators only, that is presented in Doing Business rating.

\section{Aim and tasks of research}

The aim of the work is a construction of Ukrainian business-system profile as a component of international business. The following tasks were formulated for attaining the set aim:

1. To ground the methodology of research that includes the analysis of Ukraine's place in each of 8 world ratings. is original.

2. To calculate the integral index for each country of ratings by the offered algorithm that

3. To construct the profile of Ukrainian business-system and the one of conventionally best business-system of the world on the base of integral indices.

\section{Materials and methods}

In the work was used the construction of integral index of the development and of the features of world business-system functioning, based on relative rates that in their turn characterize one or another element of each world index of 8 ones, selected for the study. At calculations of integral index the data of following indices were used:

1. Index of business doing easiness.

2. Rating of national brands.

3. Index of global competitiveness.

4. Index of budget transparence.

5. Index of investment attractiveness.

6. Index of autosorcing attractiveness.

7. Index of economic freedoms.

8. Index of trade facilitation.

Thus, the integral index for each country is calculated by this algorithm [11]:

- calculation of mean rate of each rating;

- standardization of total mark of each country in rating by division of rating mark by the mean in rating;

- separation of the standard parameters of Ukraine's position by each of 8 ratings and construction of Ukrainian business-system profile on their base;

- separation of standard rates of the best position of the country by each of 8 ratings and construction of the profile of business-system, most developed and adapted to the conditions of globalized world economy, on their base;

- calculation of integral value of the national business-systems by the formula:

$$
\mathrm{I}=\frac{\mathrm{a}}{\mathrm{A}}+\frac{\mathrm{b}}{\mathrm{B}}+\ldots+\frac{\mathrm{n}}{\mathrm{N}}
$$

where I - integral rate, a, b...n - relative rate of separate country; A, B...N-mean rate of all countries.

The author's method allows classify the countries by the degree of business-systems development in modern globalizing conditions with a possibility of revelation of the elements that need more attention as to the improvement of development level.

\section{Results}

The modeling of international business-processes in Ukraine is a complicated but rather topical task [12]. The use of one world index, from our point of view, doesn't completely provide the objectivity of research, despite its complexity and certain integrity. That is why it is more expedient to analyze the world and Ukrainian business-systems using 8 indices.

According to the every year results, many international organizations form the ratings of the countries, determining their place in the world, depending on the development of economy, social sphere, tourism and so on. The correspondent ratings were formed for 2014-2015, according to 
their data, Ukraine lost several positions. For analysis we used the data of 8 world ratings that, from our point of view, characterize the state of business-systems of the world as completely as possible and ranged them by the level of its development:

1. Business doing easiness, 2015.

2. Rating of national brands, 2015.

3. Rating of global competitiveness, 2015.

4. Rating of budget transparence, 2015.

5. Rating of investment attractiveness, 2015.

6. Rating of autosorcing attractiveness, 2015.

7. Index of economic freedoms, 2015.

8. Index of trade facilitation, 2014.

Let's consider the results of ratings more detail.

Business doing easiness. On the Fig. 1 is presented the place of Ukraine in Doing Business rating.

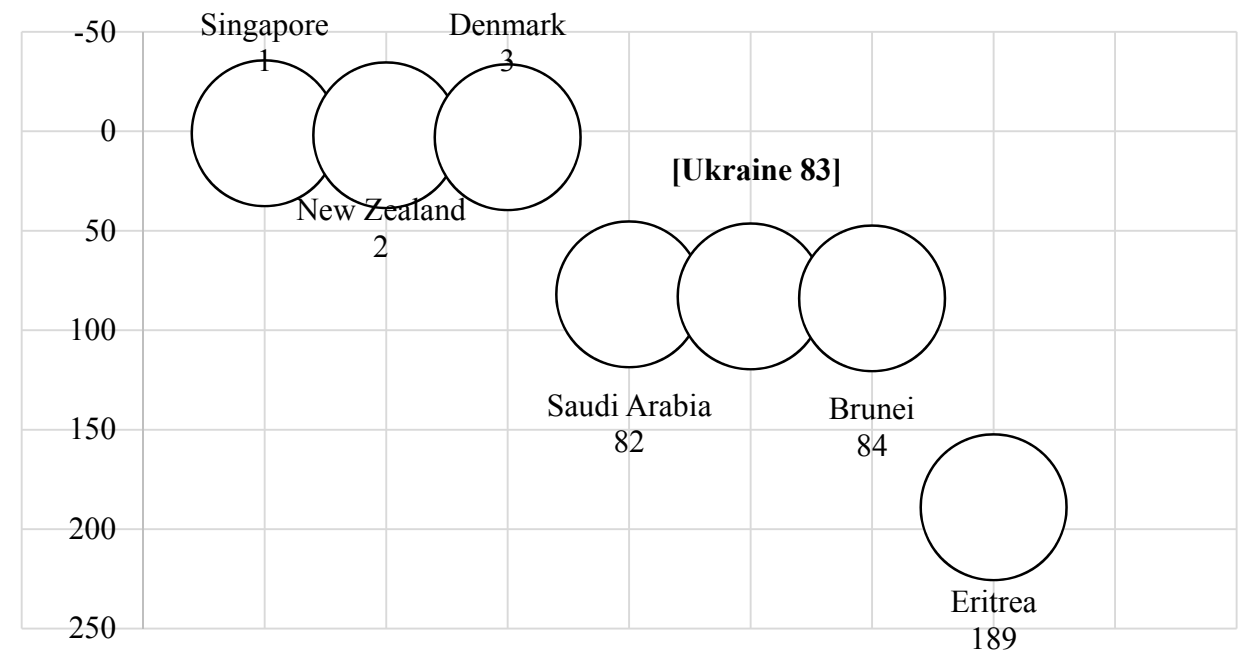

Fig. 1. The place of Ukraine in business doing easiness rating "Doing Business" Note: composed by the author by [13]

On the Fig. 2 is presented the place of Ukraine in the rating of national brands.

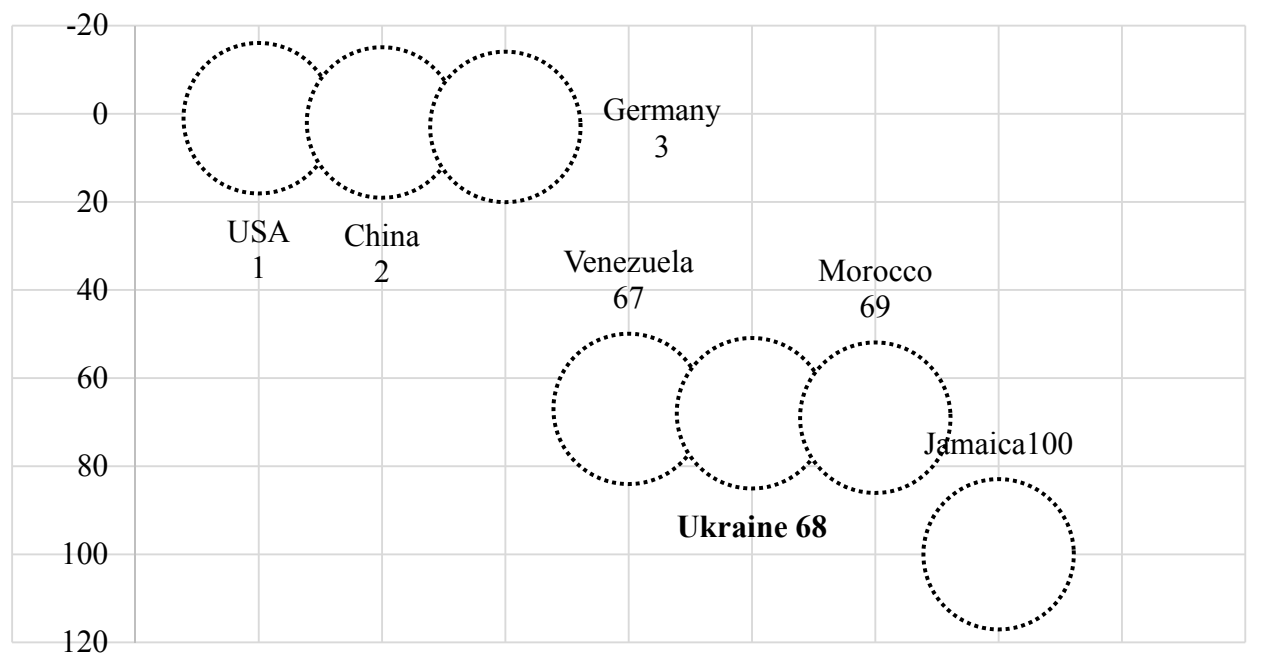

Fig. 2. The place of Ukraine in the rating of national brands Note: composed by the author by [14] 
On the Fig. 3 is presented the place of Ukraine in the rating of global competitiveness of the countries.

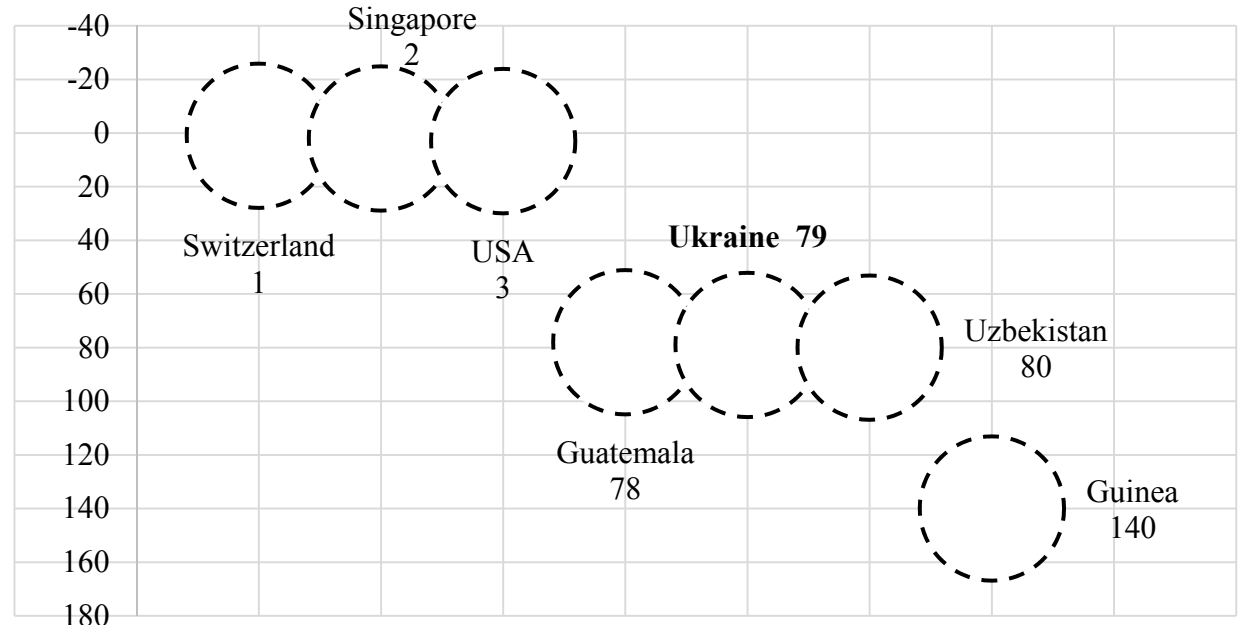

Fig. 3. The place of Ukraine in the rating of global competitiveness of the countries

Note: composed by the author by [15]

On the Fig. 4 is presented the place of Ukraine in the rating of budget transparence.

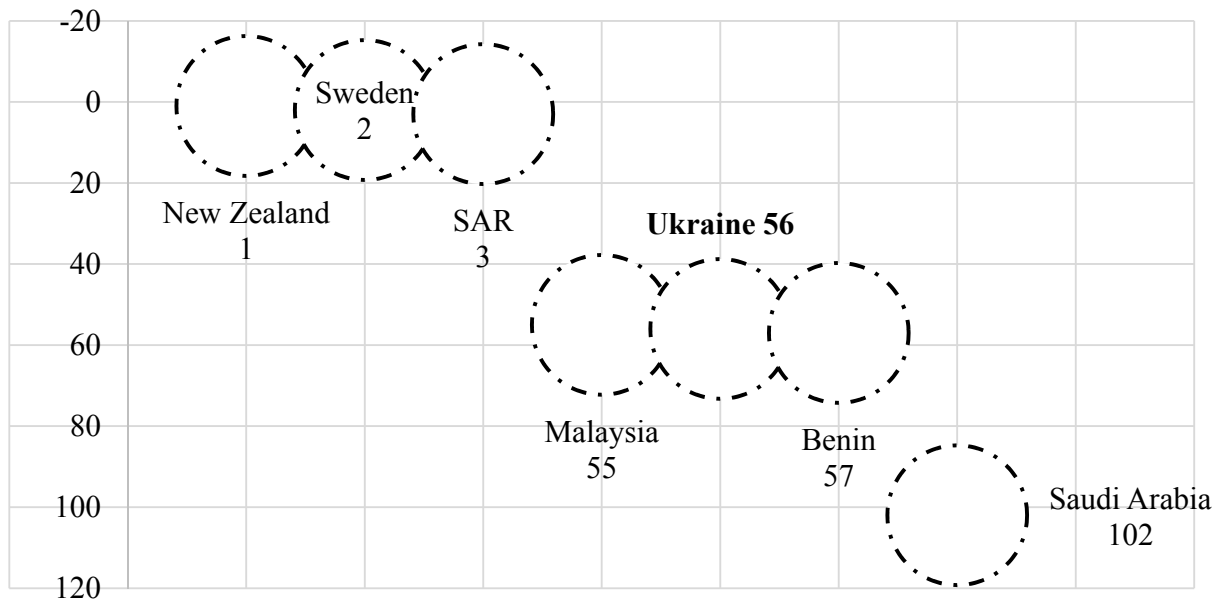

Fig. 4. The place of Ukraine in the rating of budget transparence

Note: composed by the author [16]

On the Fig. 5 is presented the place of Ukraine in the rating of investment attractiveness. On the Fig. 6 is presented the place of Ukraine in the rating of autosorcing attractiveness. On the Fig. 7 is presented the place of Ukraine in the index of economic freedoms.

On the Fig. 8 is presented the place of Ukraine in the index of trade facilitation.

For more objectivity of research we offer to construct the Ukrainian business-system profile with the calculation of its integral value. As far as each rating has its features and total scale, the rating construction will consist of several stages that is presented in the point "materials and methods".

The results of calculations are presented in the Table 1. 


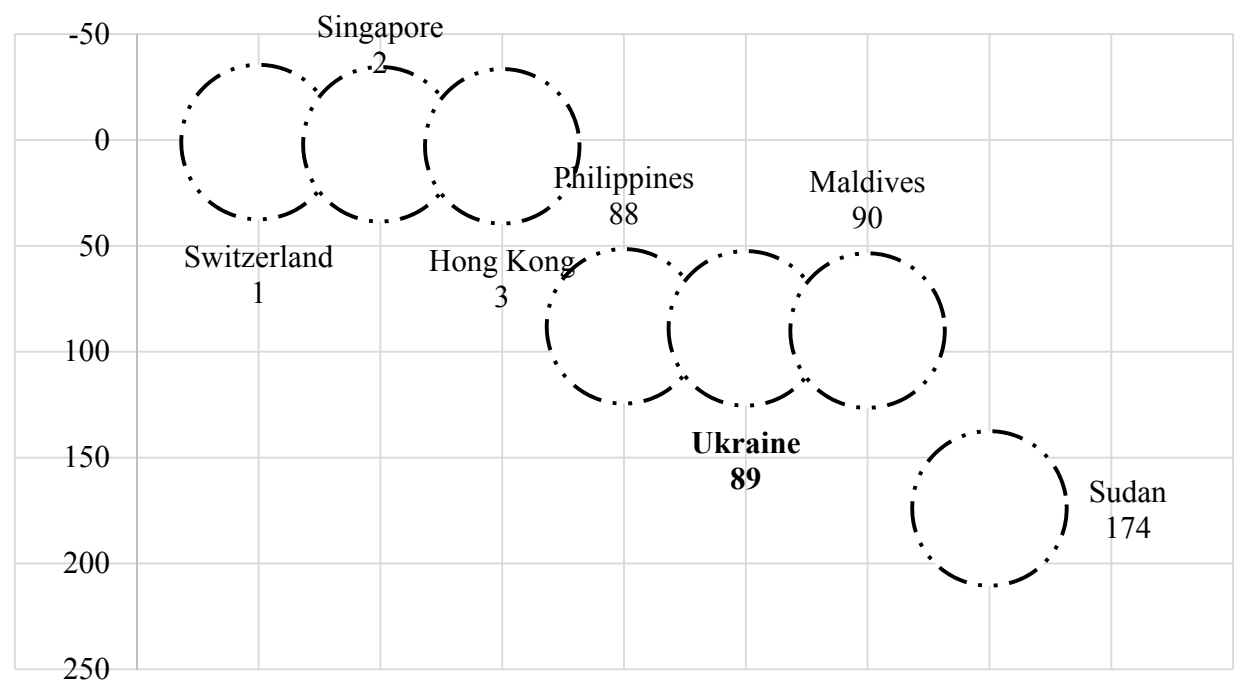

Fig. 5. The place of Ukraine in the rating of investment attractiveness Note: composed by the author by [17]

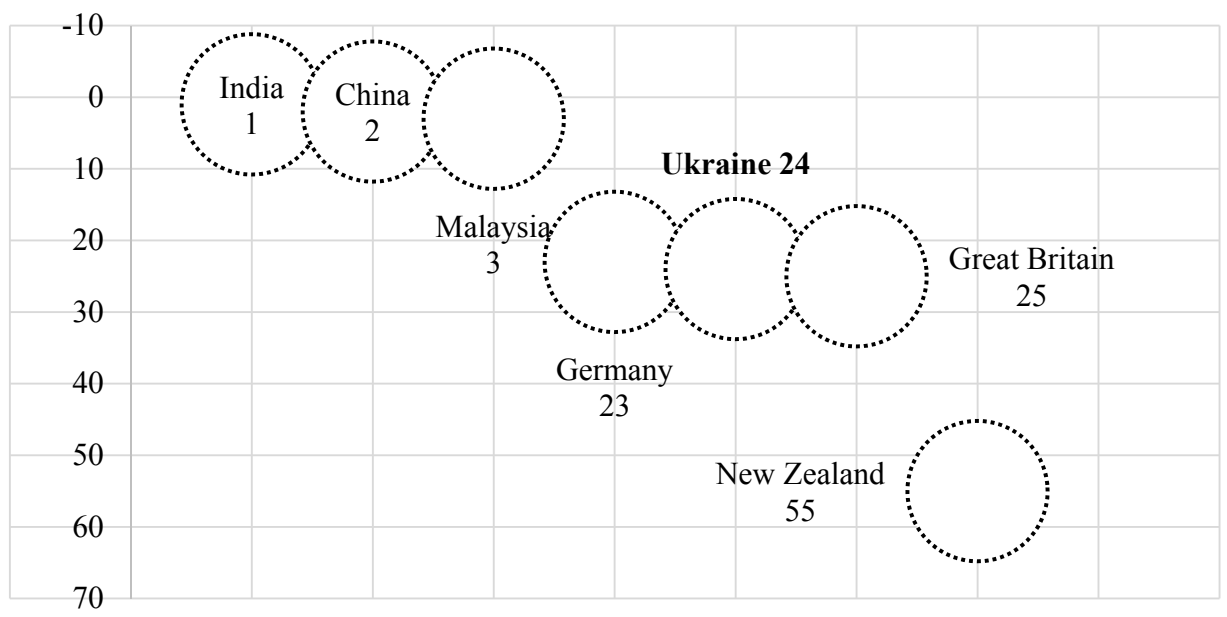

Fig. 6. The place of Ukraine in the rating of autosorcing attractiveness Note: composed by the author by [18]

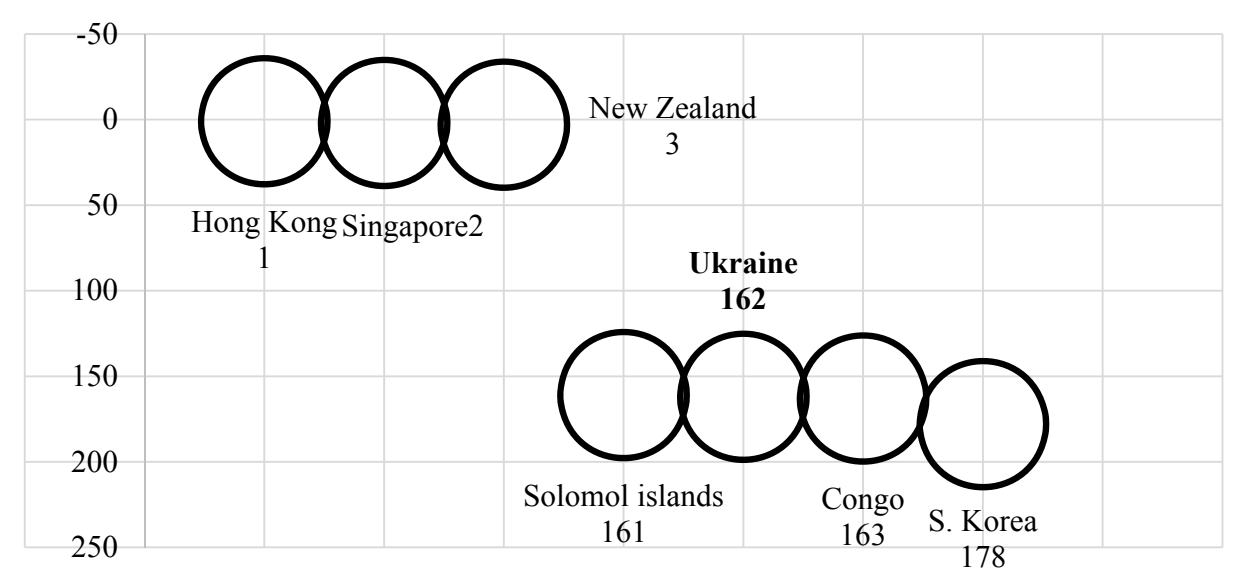

Fig. 7. The place of Ukraine in the index of economic freedoms Note: composed by the author by [19] 


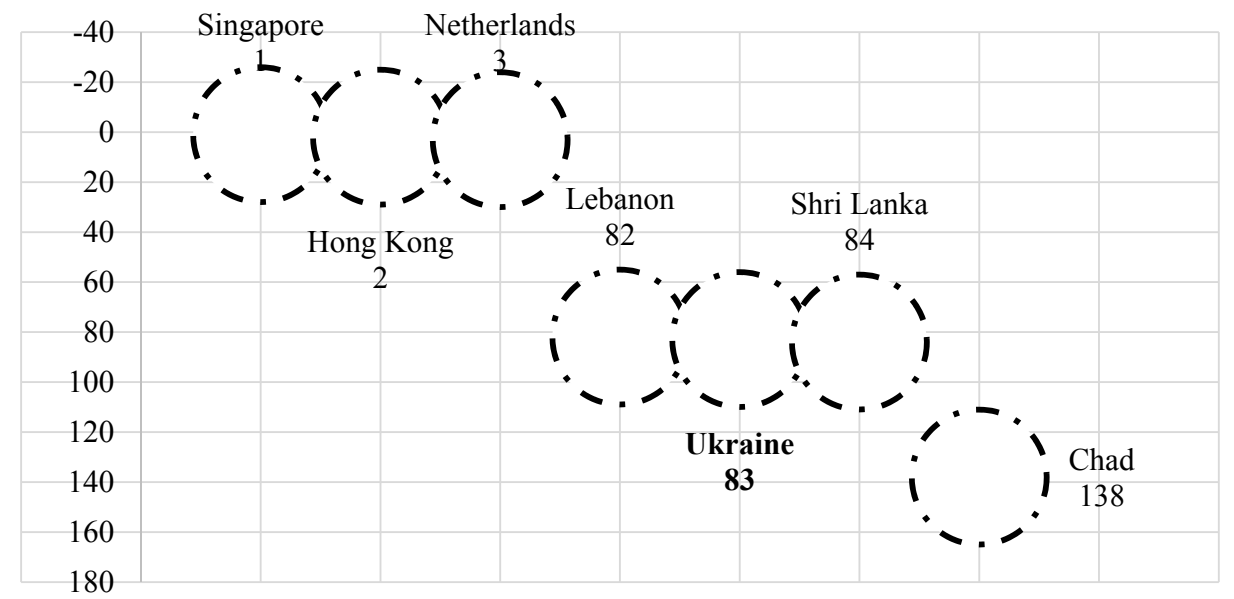

Fig. 8. The place of Ukraine in the index of trade facilitation Note: composed by the author by [20]

Table 1

The standard rates of Ukraine and of the best country by ratings

\begin{tabular}{|c|c|c|c|c|c|c|c|c|c|}
\hline \multirow{2}{*}{ Rate } & \multicolumn{8}{|c|}{ World ratings } & \multirow{2}{*}{$\begin{array}{c}\text { Integral } \\
\text { value }\end{array}$} \\
\hline & 1 & 2 & 3 & 4 & 5 & 6 & 7 & 8 & \\
\hline MAX & 1,43 & 1,34 & 1,37 & 1,94 & 1,55 & 1,33 & 1,46 & 1,46 & 11,88 \\
\hline Ukraine & 1,03 & 0,08 & 0,94 & 1,01 & 0,96 & 1,01 & 0,77 & 0,94 & 6,74 \\
\hline $\begin{array}{l}\text { The lag of } \\
\text { Ukraine from } \\
\text { the leader, \% }\end{array}$ & 27,8 & 93,7 & 31,0 & 47,7 & 38,2 & 24,0 & 47,1 & 35,5 & \\
\hline
\end{tabular}

Note: calculated by the author

At the same time we calculated the integral value of Ukrainian business-system $(6,74)$ and of business-system that is most developed and adapted to the conditions of globalized world economy $(11,88)$.

On the Fig. 9 are presented the profiles of Ukrainian business-system and of the best business-system in the world.

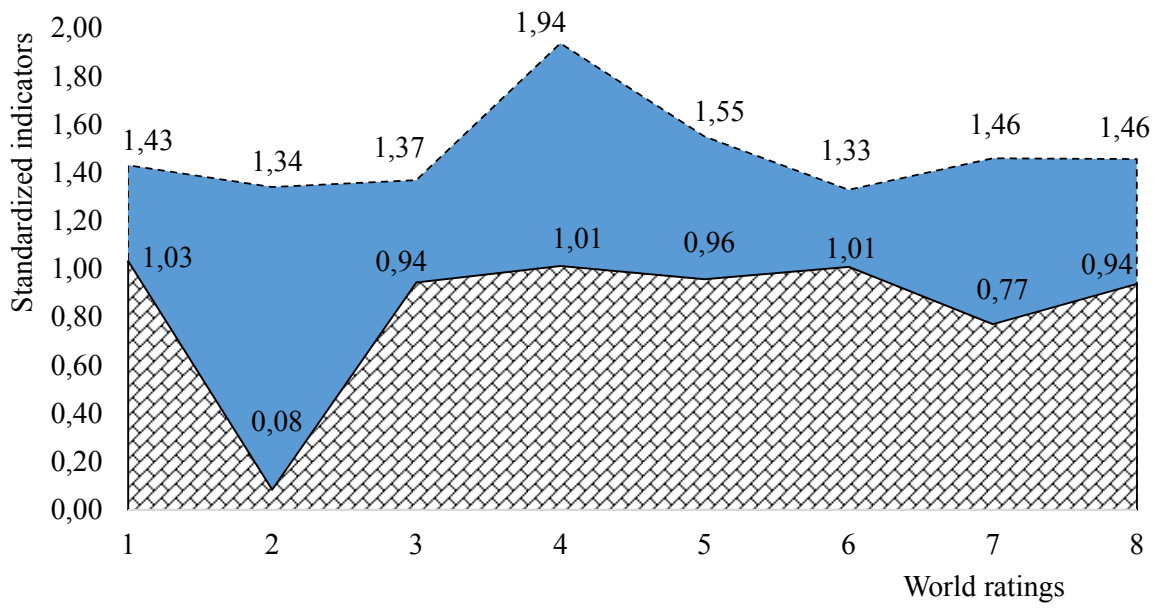

ali $\quad$ M Ukraine

Fig. 9. The profiles of Ukrainian business-system and of the best business-system in the world Note: composed by the author 
As we can see on the Table 1 and the Fig. 9, the Ukrainian business-system is inferior in its functionality according to all studied ratings. The lag from the leader is on average $43 \%$. At that the most lag is observed in the rating of national brands $(93,7 \%)$, rating of budget transparency $(47,75)$ and index of economic freedoms $(47,1 \%)$. The least percent of the lag that is however $25-30 \%$ is observed in the rating of autosorcing attractiveness $(24 \%)$, rating of business doing easiness $(27,8 \%)$, rating of global competitiveness (31\%).

\section{Discussion of the results}

The advantages of the author methods of complex study of the national business-system are the deepening of methodical bases of the study of features of the system of international business in Ukraine that can be a background of further elaboration of organizational-economic grounds of its qualitative renewal as to the needs of socio-economic interests of the country. However, the integral value and general level of the national business-system depends on the number of world ratings, selected for analysis and needs periodical recalculation, connected with annual renewal of the ratings data.

The use of the offered methodical apparatus gives a possibility to realize the analogous studies for any country of the world, to use the method of comparative analysis and to trace the dynamic changes of integral value and profile of the national business-systems.

The offered methodology uses the standard algorithm of calculation of integral value, but it was used for the first time for the complex study of national business-systems and will be improved by the author at further studies.

\section{Conclusions}

As the result of research:

1. The author's methodology of the study that includes the analysis of the place of Ukraine in each of 8 world ratings, each of which, from the author's point of view, characterizes the certain part of Ukrainian business-system development, was grounded. Especially it was revealed, that Ukraine has problems in each indicator of business-system: trade, regulatory policy, competitiveness, innovative activity, normative-legislative sphere and so on. The best position of Ukraine is observed only in autosorcing sphere that can be explained by the high level of professional education and ability of distant employment, when the numerous permissions and other regulatory procedures are not needed.

2. The components of integral index of business-system state were calculated for each country including Ukraine, using the author's algorithm.

3. The profile of Ukrainian and conventionally best business-system was constructed that allowed reveal the main problems in the system of international business, and the foreign experience allows form the system of economy stabilization taking into account the national specificity. The results of analysis testify to the necessity of introduction of effective organizational-economic principles, directed on qualitative improvement of Ukrainian business-system by the separate components and in the whole.

\section{References}

[1] Kulik, Yu. (2011). Analiz diyal'nosti biznes-systemy u konkurentnomu seredovyshchi. Ekonomichnyy analiz, 8 (2), 215-219.

[2] Vedennya biznesu v Ukrayini (2015). BDO, 24. Available at: http://www.eba.com.ua/static/ members_reviews/DBiU_BDO_May_2015_ukr.pdf

[3] Rashkovan, V., Pokidin, D. (2016). Klasternyy analiz biznes-modeley ukrayins'kykh bankiv: zastosuvannya neyronnykh merezh Kokhonena. Visnyk Natsional'noho banku Ukrayiny, 13-40. Available at: https://bank.gov.ua/doccatalog/document?id=42352928

[4] Ayadi, R., De Groen, W. P., Sassi, I., Mathlouthi, W., Rey, H., Aubry, O. (2015). Banking Business Models Monitor 2015 EUROPE. 125. Available at: https://www.ceps.eu/system/files/Banking-Business-Models-Monitor-Europe-2015.pdf 
[5] Financial systems in Europe and in the US: structural differences where banks remain the main source of finance for companies (2015). Research Paper, 12. Available at: http://www.savings-banks.com/SiteCollectionDocuments/Financial\%20systems\%20in\%20Europe\%20and\%20in\%20 the \%20US.FINAL.pdf

[6] Mendis, A. (2015). Asia Pacific Business: Comparing the National Business Systems of Japan and China. Available at: https://www.linkedin.com/pulse/comparing-national-business-systems-japan-china-avishka-mendis

[7] Wuren, S. (2010). Diffierent business systems in German, Japan and USA. Academia, 8. Available at: https://www.academia.edu/6819194/Diffierent_business_systems_in_German_Japan_and_USA

[8] Pereira, V., Malik, A., Froese, F. J. (2015). National Business Systems in Asian countries: Impact on Human Resource Management, Employment Relations Practices and Organisation Behaviour. Special issue call for papers from Journal of Asia Business Studies. Available at: http://emeraldgrouppublishing.com/ products/journals/call_for_papers.htm?id=5850

[9] Bendt, F., Sanne, J. (2010). The Korean Business Systems-national characteristics and the impact of the FTA between Korea and the EU from a European Corporate Perception. International Business and Trade, 113. Available at: https:/gupea.ub.gu.se/handle/2077/22604

[10] Study on India's Regional Trade Agreements Impact on Indian Economy (2010). Assocham, 84. Available at: http://www.finpro.fi/documents/10304/216326/Intian+vapaakauppasopimukset.pdf

[11] Yurchenko, S. A. (2006). Infrastruktura mira. Kharkiv, 328.

[12] Shkil', N. H. (2014). Modelyuvannya mizhnarodnykh biznes-protsesiv v Ukrayini. Innovatsiyna ekonomika, 6, 58-65.

[13] Doing Business (2016). 348. Available at: http://www.doingbusiness.org/rankings

[14] Anholt-GfK Nation Brands Index (2015). Available at: http://nation-brands.gfk.com

[15] The Global Competitiveness Index (2016). World economic forum, 2. Available at: http:// www3.weforum.org/docs/gcr/2015-2016/GCR_Flyer_2015-16.pdf

[16] Open Budget Survey (2015). Internationalbudget, 71. Available at: http://www.internationalbudget.org/wp-content/uploads/OBS2015-Report-English.pdf

[17] International Business Compass (2016). BDO, 12. Available at: https://www.bdo-ibc.com/fileadmin/dokumente/BDO-IBC-Summary-2016_ENG.pdf

[18] Global Services Location Index (2016). ATKearney, 13. Available at: https://www.atkearney. com/documents/10192/7094247/On+the+Eve+of+Disruption.pdf/49fa89fa-7677-4ab8-8854-5003af40fc8e

[19] Index of Economic Freedom (2016). Executive Highlights, 9. http://www.heritage.org/index/ pdf/2016/book/executivehighlights.pdf

[20] Composition and Computation of the Enabling Trade Index (2014). World economic forum, 343. Available at: http://www3.weforum.org/docs/WEF_GlobalEnablingTrade_Report_2014.pdf 